\title{
COMPARATIVE STUDY OF THREE DIMENSIONAL AND TWO DIMENSIONAL ULTRASOUND MARKERS OF OVARIAN RESERVE IN WOMEN UNDERGOING INTRACYTOPLASMIC SPERM INJECTION (ICSI)
}

\author{
By \\ Yehia Abd Elsalam Wafa, Mohamed Mohamed Gebril, \\ Ahmed Mohamed Rammah and Hazem Mohamed Tawfik Nada \\ Department of Obstetrics and Gynecology, Faculty of Medicine, Al-Azhar University
}

\begin{abstract}
Background: Over the last two decades, various ultrasound markers have been investigated to evaluate their role in the prediction of ovarian function and hence reserve. The three most common markers that have been specifically addressed are ovarian volume, antral follicle count (AFC) and ovarian vascularity.

Objective : To evaluate differences between three-dimensional (3D) and two dimensional(2D) ultrasound markers of ovarian reserve (antral follicle count and ovarian volume ) in women undergoing investigation for subfertility before intra cytoplasmic sperm injection.

Patients and methods: This study was a prospective observational study including 50 women who attend the Infertility Clinic at Al-Azhar International Islamic Center for population studies and researches.

Intervention: Measurement of cycle day three follicle stimulating hormone (CD3 FSH), luteinizing hormone (LH), prolactin (PRL), estradiol (E2), anti Mullerian hormone (AMH), thyroid stimulating hormone (TSH) and ovarian reserve antral follicle count (AFC) and ovarian volume (OV) \}by transvaginal tow dimensional (2D) and three dimensional (3D) ultrasound, patients were subjected to long ovulation induction protocol. Assessment of follicles number, quality and number of oocyte retrieved was done.
\end{abstract}

Results: There was no difference between 2D and 3D ultrasound in the assessment of antral follicle count. The difference between 2D and 3D ultrasound in the assessment of ovarian volume was minimal and nonsignificant.

Conclusions: Application of transvaginal sonography in evaluation of ovarian reserve proved to be of important value in the assessment of poor and good responders for ICSI treatment, to avoid expensive IVF cycle cancellation.

\section{INTRODUCTION}

The ovary is no exception to the ravages of ageing, which occur in every organ of the body. In contrast to somatic cells, the germ line oogonia are potentially immortal with a minority being passed to the next generation although it has been suggested that germ line stem cells can be found in the adult mouse ovary from which new oogonia can be formed by mitosis and meiosis. In the human male 
the germ cells become quiescent and maintain their stem cell identity. In contrast, in the human female, between 12 and 18 weeks, the germ cells enter meiosis and differentiated prior to birth. Primordial follicles and oocytes are derived during fetal life and the oogonial stem cell line is lost before birth (Yohnson et al., 2011).

Over the last few years, there have been extensive efforts to develop hormone and / or biophysical tests for ovarian ageing by estimating the total number of oocytes left in the ovary (ovarian reserve), a prediction of the number of remaining years of reproductive life could be made as well as the likely success of ART such as IVF. None of the tests measures the total number of oocytes directly. Rather, they assume that the number of the developing follicles is directly related to the total oocyte pool (Tevelde and Pearson, 2010).

Many tests have been developed to screen for diminished ovarian reserve. Traditional methods used to predict prospectively response to ovarian stimulation have included mainly the measurement of baseline cycle day 3 serum concentrations of hormones such as FSH, estradiol, and inhibin or ultrasonographic tests such as pretreatment ovarian volume and the number of early antral follicles (Penarrubia et al., 2013). Normal baseline values are not a guarantee that an endocrine organ is functioning normally and non-response to ovarian stimulation in normogonadotropic women has been reported. Provocative dynamic tests such as clomiphene citrate challenge test (CCCT), determining $\mathrm{E}_{2}$ response in gonadotropin releasing hormone $(\mathrm{GnRH})$ agonist stimulation test or the exogenous FSH ovarian reserve test (EFORT) seems to improve the predictive value of the basal hormone levels (Hansen et al., 2017).

The aim of the present work was to evaluate the differences between threedimensional (3D) and two dimensional ultrasound markers of ovarian reserve (antral follicle count and ovarian volume) in women undergoing investigation for subfertility before intra cytoplasmic sperm injection (ICSI).

\section{PATIENTS AND METHODS}

In this prospective study, 50 women attended at the Infertility Clinic, International Islamic Center for population studies and researches. All the patients have met the following criteria: (i) An early follicular phase FSH level of $<10 \mathrm{mIU} / \mathrm{ml}$, (ii) No ovarian cysts $\geq 10$ $\mathrm{mm}$ in diameter, (iii) No history of partial or complete surgical resection of the ovary, (iv) No history or current of ovarian endometriosis, (v) No hormonal or ultrasonographic features of polycystic ovaries,(vi) Age of patients was below 40 years, (vii) Non-smokers, (viii) No male infertility. Patients with history of poor ovarian reserve were excluded. All patients were subjected to full history, examination and ultrasound assessment at the first visit. Serum FSH, LH, prolactin, E2, AMH and TSH were measured on day 2 or 3 of the menstrual cycle. Ovarian reserve (antral follicle count and ovarian volume) was done for each patient at day two or three of the cycle using transvaginal 2D and 3D ultrasonography simultaneously. 
Statistical Analysis: The collected data were organized, tabulated and statistically analyzed using SPSS software (Statistical Package for the Social Sciences, version 16, SPSS Inc. Chicago, IL, USA). For quantitative data, the range, mean and standard deviation were calculated. For qualitative data, which described a categorical set of data by frequency, percentage or proportion of each category, comparison between two groups and more was done using Chi-square test $\left(\chi^{2}\right)$. For comparison between means, paired student $\mathrm{t}$-test was used. Correlation between variables was evaluated using Pearson's correlation coefficient (r). Significance was adopted at $\mathrm{p}<0.05$ for interpretation of results of tests of significance .

\section{RESULTS}

The mean AFC by 2D\&3D ultrasound was 9.00 \pm 1.88 (19 women has 6-8 follicles, 26 women has 9-11 follicles and 5 women has 12-13 follicles). The mean ovarian volume was $3.89 \pm 0.45 \mathrm{~cm}^{3}$ by using 2D ultrasound (27 of women was 3$<4 \mathrm{~cm}^{3}$, and 23 was $4-<5 \mathrm{~cm}^{3}$ ), and by 3D ultrasound the mean ovarian volume was $4.06 \pm 0.46 \mathrm{~cm}^{3}$ (20 of women was 3-<4 $\mathrm{cm}^{3}, 29$ was $4-<5 \mathrm{~cm}^{3}$ and 1 woman was 5 $\mathrm{cm}^{3}$ ). $\mathrm{P}$ value was $>0.05$ which is nonsignificant (Table 1).

Table (1): Ovarian reserve detected among the studied women undergoing intracytoplasmic sperm injection (ICSI) using two and three dimentional (2D and 3D) transvaginal ultrasonography simultaneously $(n=50)$.

\begin{tabular}{|c|c|c|c|c|c|}
\hline \multirow[t]{2}{*}{ Parameters } & \multicolumn{2}{|c|}{$\begin{array}{c}\text { Two dimensional } \\
\text { (2D) }\end{array}$} & \multicolumn{2}{|c|}{$\begin{array}{c}\text { Three } \\
\text { dimensional } \\
\text { (3D) }\end{array}$} & \multirow[t]{2}{*}{$\mathbf{P}$} \\
\hline & $\mathbf{N}$ & $\%$ & $\mathbf{N}$ & $\%$ & \\
\hline \multicolumn{6}{|l|}{ Antral follicle count (AFC): } \\
\hline $6-8$ & 19 & 38.0 & 19 & 38.0 & \multirow[t]{5}{*}{1.000} \\
\hline $9-11$ & 26 & 52.0 & 26 & 52.0 & \\
\hline $12-13$ & 5 & 10.0 & 5 & 10.0 & \\
\hline Range & \multirow{2}{*}{\multicolumn{2}{|c|}{$\begin{array}{c}6-13 \\
9.00 \pm 1.88\end{array}$}} & \multirow{2}{*}{\multicolumn{2}{|c|}{$\begin{array}{c}6-13 \\
9.00 \pm 1.88\end{array}$}} & \\
\hline Mean \pm SD & & & & & \\
\hline $\begin{array}{l}\mathrm{t} \text {-test } \\
\mathrm{P}\end{array}$ & \multicolumn{4}{|c|}{$\begin{array}{l}0.000 \\
1.000\end{array}$} & \\
\hline \multicolumn{6}{|l|}{ Ovarian volume $\left(\mathrm{cm}^{3}\right)$ : } \\
\hline $3-<4$ & 27 & 54.0 & 20 & 40.0 & \multirow[t]{7}{*}{$>0.05$} \\
\hline $4-<5$ & 23 & 46.0 & 29 & 58.0 & \\
\hline 5 & 0 & 0 & 1 & 2.0 & \\
\hline Range & \multicolumn{2}{|c|}{$3.00-4.70$} & \multicolumn{2}{|c|}{$3.20-5.00$} & \\
\hline Mean \pm SD & \multicolumn{2}{|c|}{$3.89 \pm 0.45$} & \multicolumn{2}{|c|}{$4.06 \pm 0.46$} & \\
\hline t-test & \multicolumn{4}{|c|}{1.912} & \\
\hline $\mathrm{P}$ & \multicolumn{4}{|c|}{0.059} & \\
\hline
\end{tabular}


2D \& 3D ultrasound shows poor ovarian reserve:

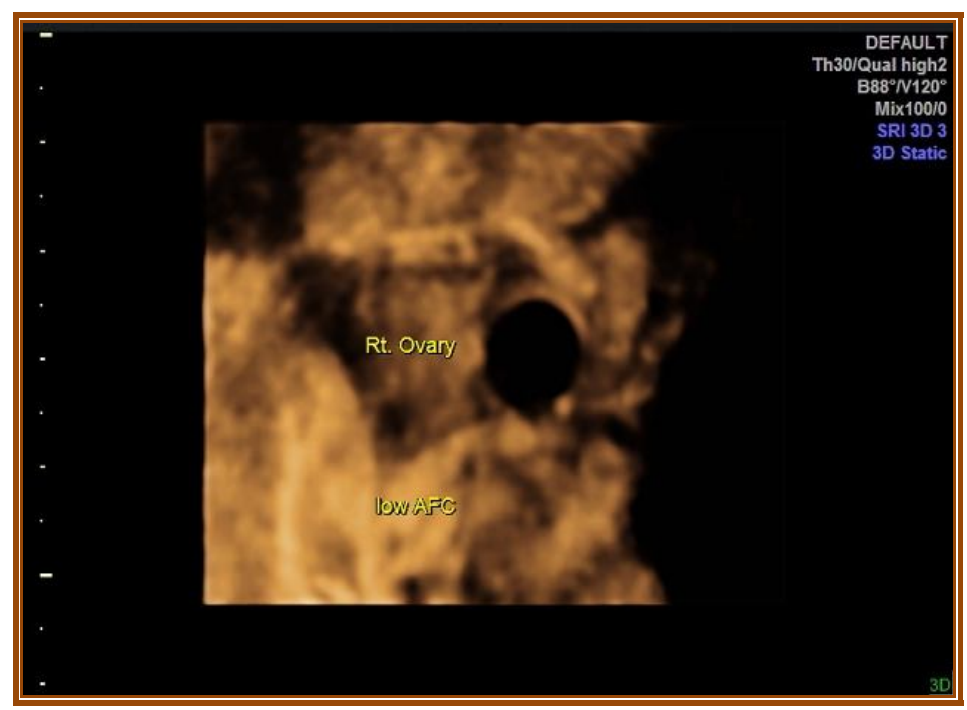

Figure (1): 3D of the ovary shows antral follicle count (poor ovarian reserve).

Figure (2): 2D \& 3D of the ovary shows antral follicle count (poor ovarian reserve).
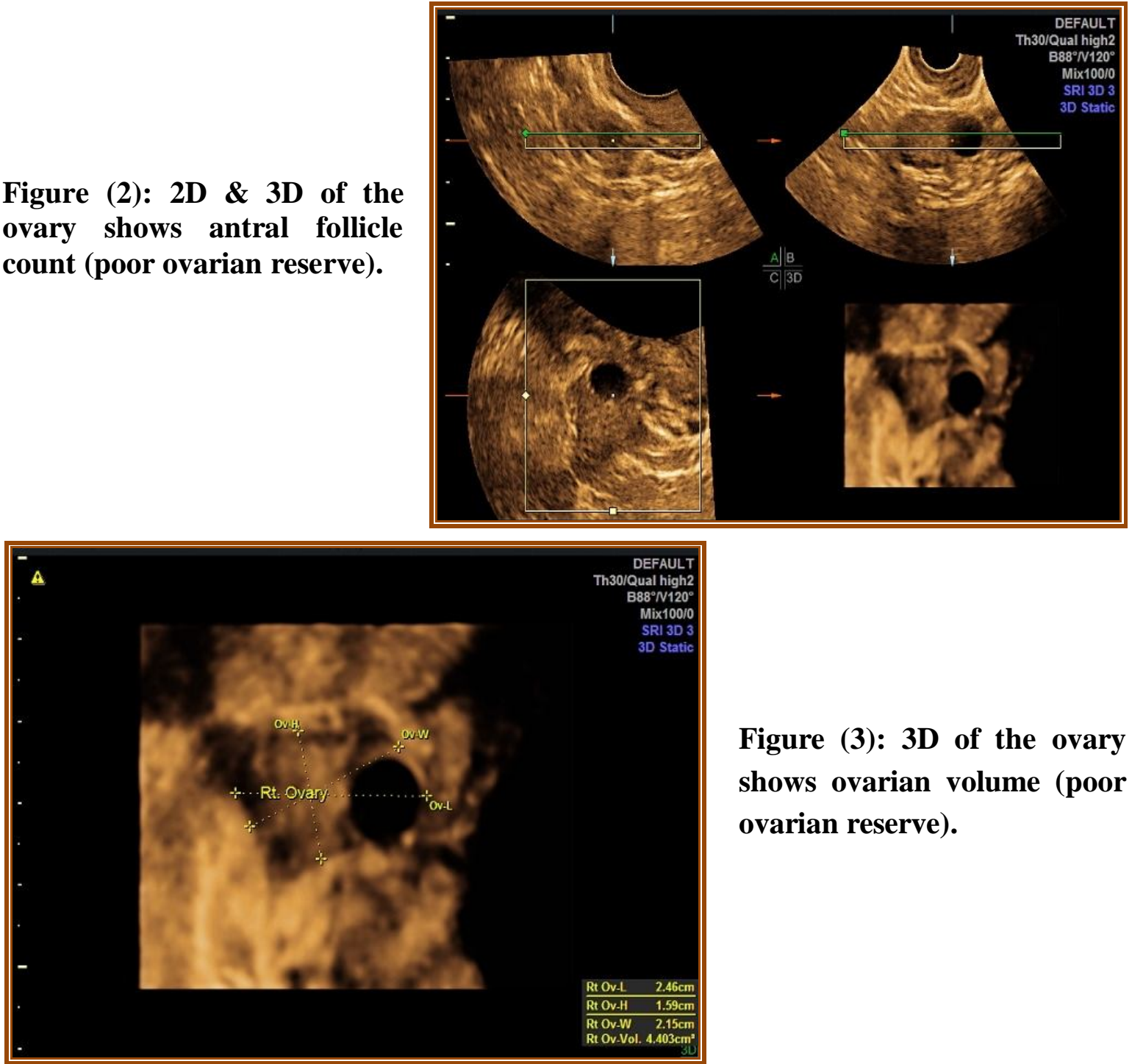

Figure (3): 3D of the ovary shows ovarian volume (poor ovarian reserve). 
国 2D \& 3D ultrasound shows average ovarian reserve Lt ovary:

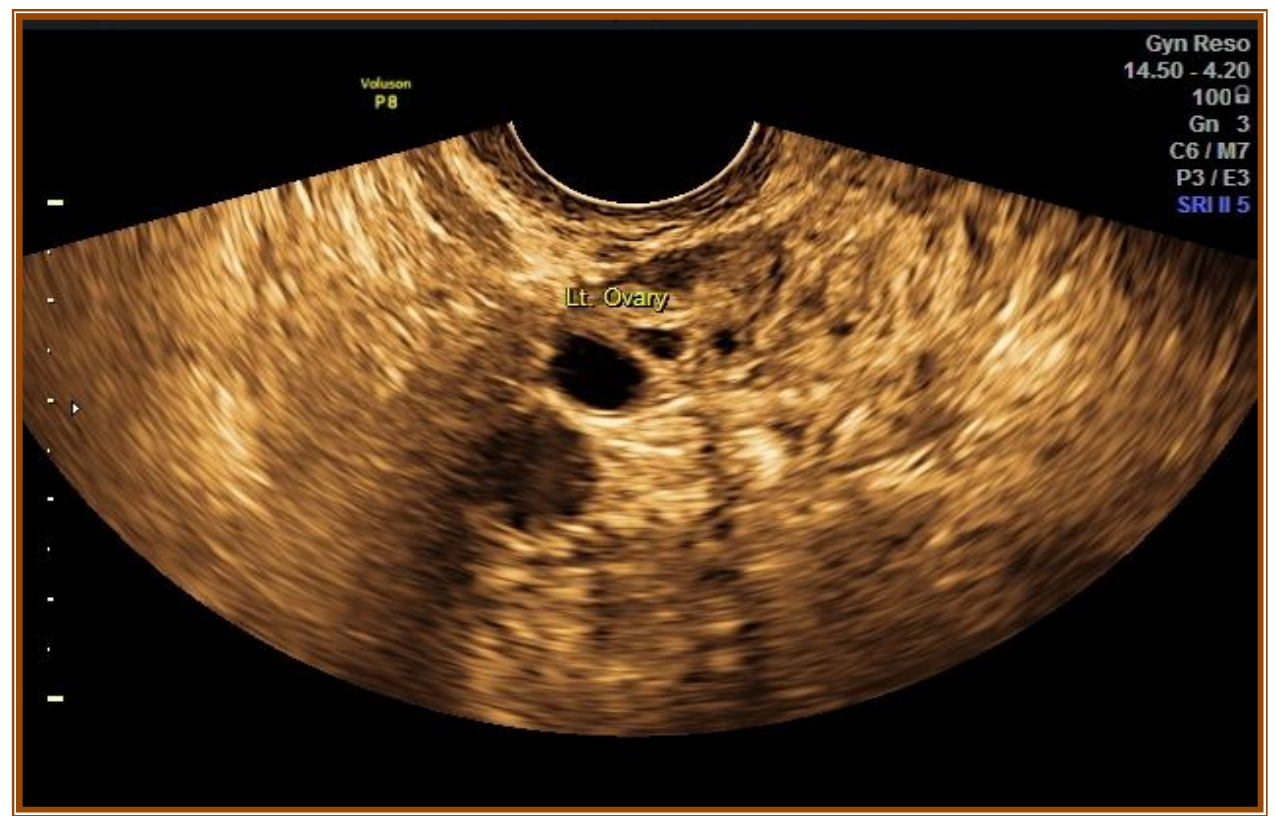

Figure (4): 2D of the Lt ovary shows antral follicle count (average ovarian reserve).

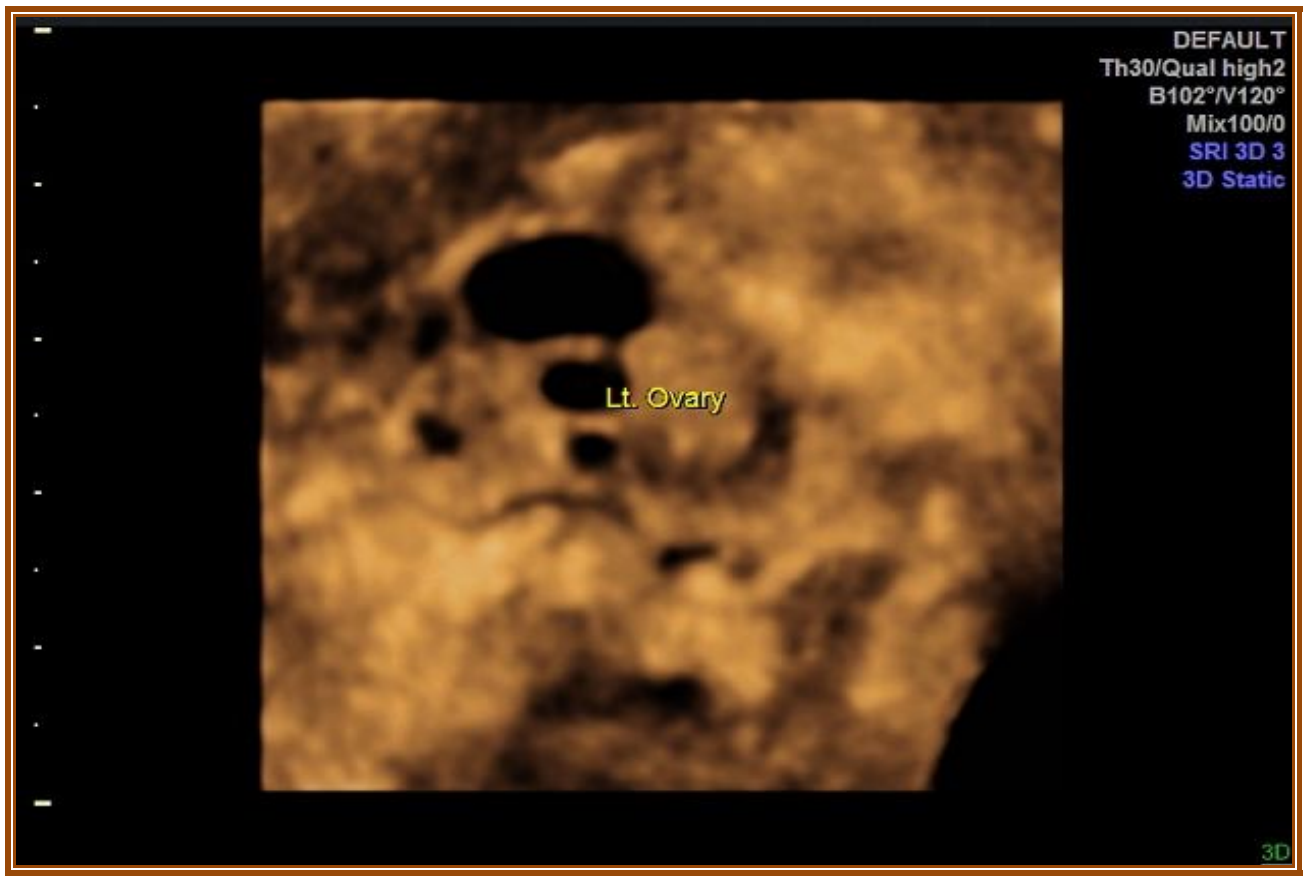

Figure (5): 3D of the Lt ovary shows antral follicle count (average ovarian reserve). 


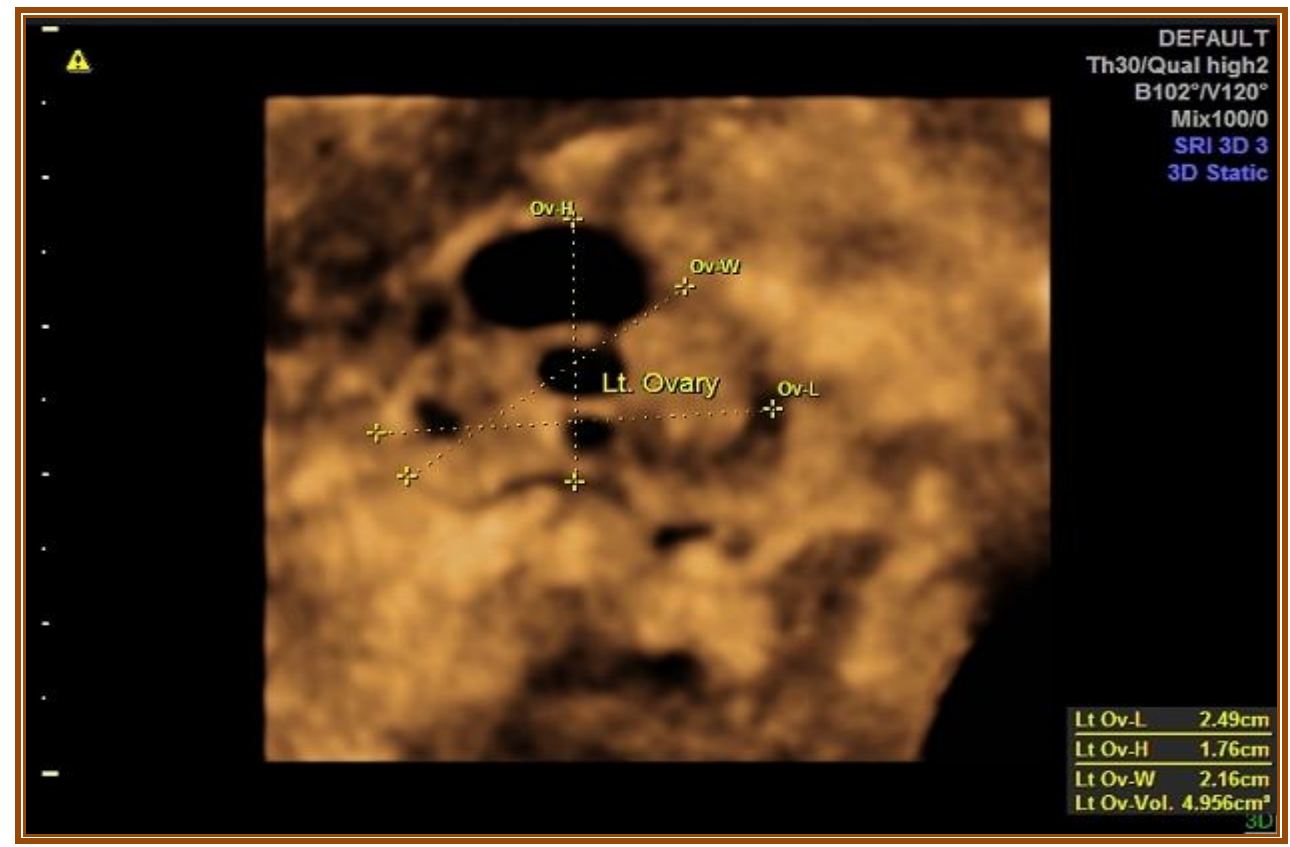

Figure (6): 3D of the Lt ovary shows ovarian volume (average ovarian reserve).

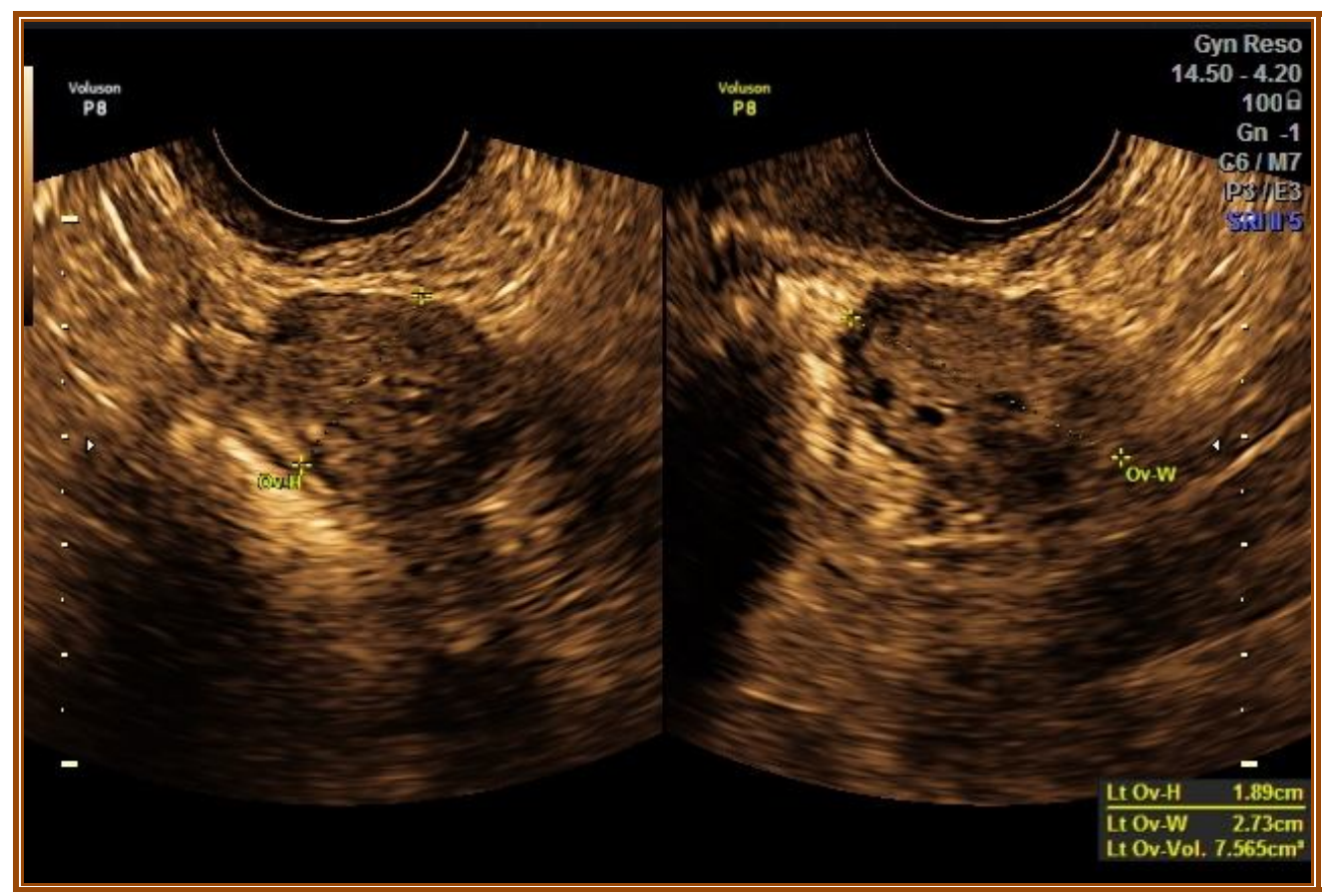

Figure (7): 2D of the Lt ovary shows ovarian volume (average ovarian reserve). 


\section{䀏 Rt ovary:}

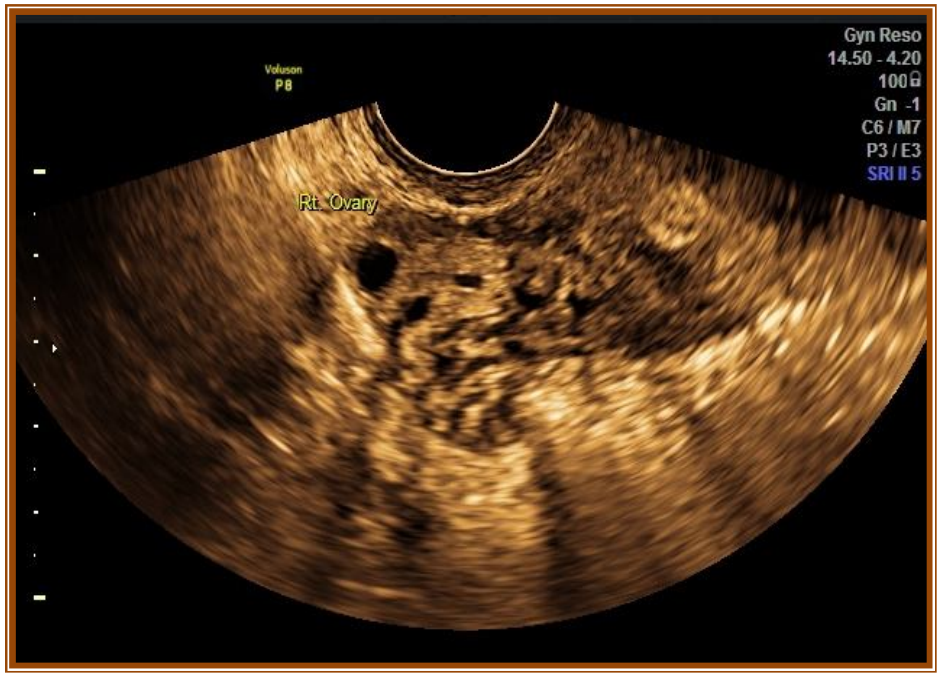

Figure (8): 2D of the Rt ovary shows antral follicle count (average ovarian reserve).

Figure (9): 3D of the Rt ovary shows antral follicle count (average ovarian reserve).
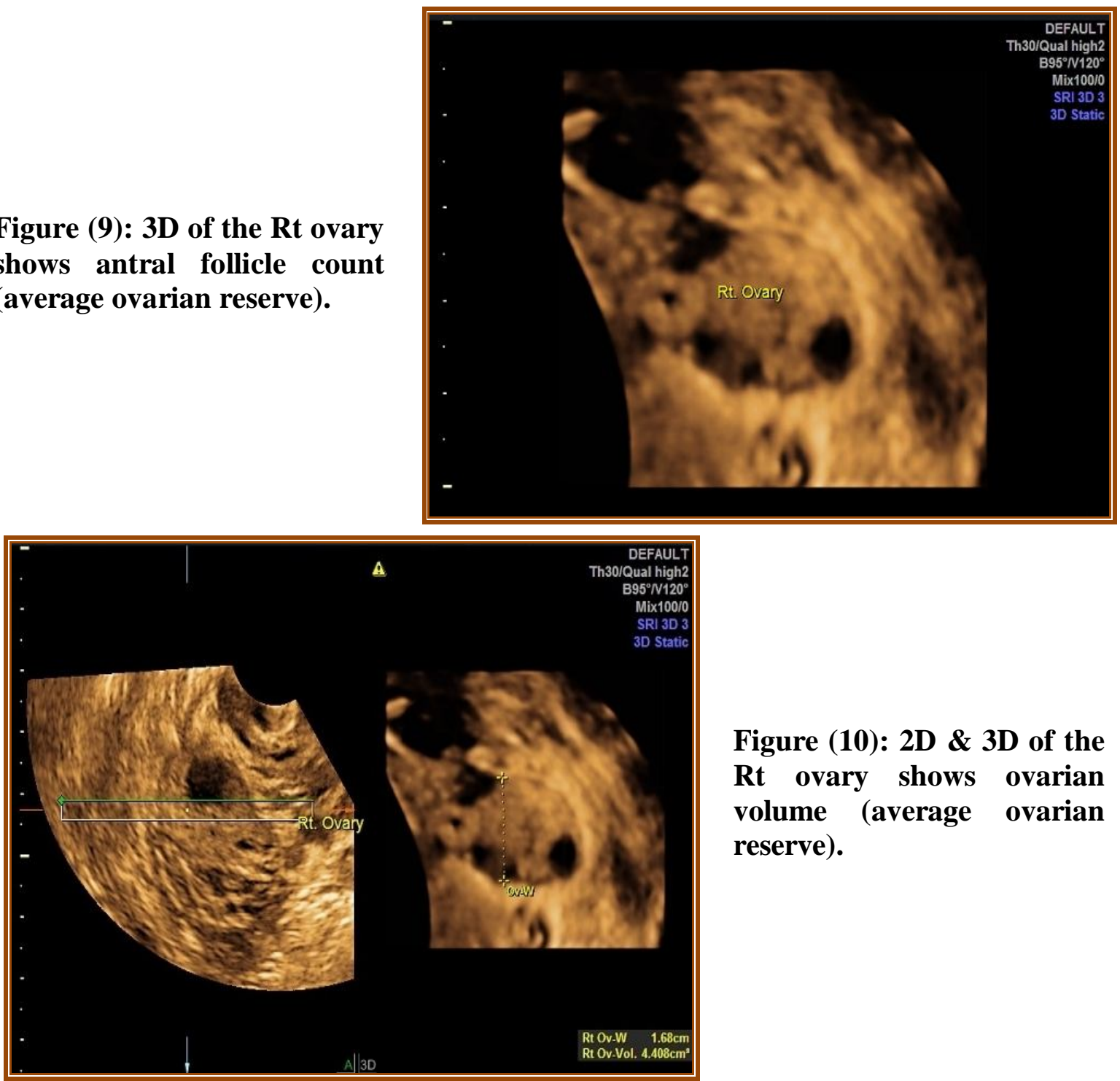

Figure (10): 2D \& 3D of the Rt ovary shows ovarian volume (average ovarian reserve). 
In this study, the AMH of the studied women ranged between 1.90-4.60 ng/ml. The mean of $\mathrm{AMH}$ was $2.89 \pm 0.66$. $\mathrm{P}$ value between AFC \& AMH was >0.05, P value between ovarian volume(2D) \& $\mathrm{AMH}$ was $>0.05$, and $\mathrm{P}$ value between ovarian volume(3D) \& AMH was $>0.05$ which is non-significant (Table2).

Table (2): Correlation between Anti-Mullerion hormone (AMH) level and ovarian reserve (antral follicle count and ovarian volume) among the studied women undergoing intracytoplasmic sperm injection (ICSI) $(n=50)$.

\begin{tabular}{|l|c|c|}
\hline \multirow{2}{*}{ Patients } & \multicolumn{2}{|c|}{ Level of AMH (ng/ml) } \\
\cline { 2 - 3 } & R & P \\
\hline Antral follicle count $(\mathbf{A F C}) \mathbf{2 D} \&$ 3D & 0.138 & $>0.05$ \\
\hline Ovarian volume $(\mathbf{O v V})\left(\mathbf{c m}^{\mathbf{3}}\right) \mathbf{2 D}$ & 0.130 & $>0.05$ \\
\hline Ovarian volume $(\mathbf{O v V})\left(\mathbf{c m}^{\mathbf{3}}\right)$ 3D & 0.132 & $>0.05$ \\
\hline
\end{tabular}

r=Correlation Coefficient)

FSH of the studied women was 3.00-9.20 $\mathrm{mIU} / \mathrm{ml}$, with a mean of $\mathrm{FSH}$ was $6.74 \pm 1.74$, LH was $1.40-8.20 \mathrm{mIU} / \mathrm{ml}$, with a mean of $\mathrm{LH}$ was $4.47 \pm 1.50$, PRL was $1.43-51.90 \mathrm{ng} / \mathrm{ml}$, with a mean of PRL was $11.25 \pm 8.05$. E2 was 1.40 -
$80.00 \mathrm{pg} / \mathrm{ml}$, with a mean of E2 was 19.34 \pm 15.04 . AMH was $1.90-4.60 \mathrm{ng} / \mathrm{ml}$, with a mean of AMH was 2.89 \pm 0.66 . TSH was $1.30-4.00 \mathrm{miu} / \mathrm{l}$, with a mean of TSH was $2.75 \pm 0.82$ (Table 3).

Table (3): Hormonal profile in early follicular phase among the studied women undergoing intracytoplasmic sperm injection (ICSI) $(n=50)$.

\begin{tabular}{|l|c|c|}
\hline \multirow{2}{*}{ Pariables } & \multicolumn{2}{|c|}{ Patients } \\
\cline { 2 - 3 } & Range & Mean \pm SD \\
\hline $\begin{array}{l}\text { Follicle stimulating hormone } \\
\text { (FSH) (mIU/ml) }\end{array}$ & $3.00-9.20$ & $6.74 \pm 1.74$ \\
\hline $\begin{array}{l}\text { Lutenizing hormone (LH) } \\
\text { (mIU/ml) }\end{array}$ & $1.40-8.20$ & $4.47 \pm 1.50$ \\
\hline $\begin{array}{l}\text { Prolactin hormone (PRL) } \\
\text { (ng/ml) }\end{array}$ & $1.43-51.90$ & $11.25 \pm 8.05$ \\
\hline Estradiol (E2) (pg/ml) & $1.40-80.00$ & $19.34 \pm 15.04$ \\
\hline $\begin{array}{l}\text { Anti-Mullerian hormone } \\
\text { (AMH) (ng/ml) }\end{array}$ & $1.90-4.60$ & $2.89 \pm 0.66$ \\
\hline $\begin{array}{l}\text { Thyroid stimulating hormone } \\
\text { (TSH) (mIU/L) }\end{array}$ & $1.30-4.00$ & $2.75 \pm 0.82$ \\
\hline
\end{tabular}




\section{DISCUSSION}

Ovarian reserve is the term that refers to a woman current supply of ova is associated with the reproductive potential. Determination of ovarian reserve is important before any expensive IVF treatment is undertaken. Identification of both low and high responders prior to treatment may decrease cycle cancellation rate as well as side effects, such as ovarian hyper stimulation syndrome. Several methods were used to evaluate ovarian reserve in women during childbearing period, such as static tests, dynamic tests, ovarian biopsy and ultrasonographic assessment. Measuring ovarian volume has been suggested as a possible screening test to assess a woman's ovarian reserve. In our study, we found that the mean ovarian volume was $3.89 \pm 0.45 \mathrm{~cm} 3$ by using 2D ultrasound(27 of women was 3$<4^{\mathrm{cm} 3}$, and 23 was $4-<5^{\mathrm{cm} 3}$ ), and by $3 \mathrm{D}$ ultrasound the mean ovarian volume was $4.06 \pm 0.46^{\mathrm{cm} 3}$ (20 of women was $3-<4 \mathrm{~cm} 3$, 29 was $4-<5^{\mathrm{cm} 3}$ and 1 women was $5^{\mathrm{cm} 3}$ ), with no significant difference. This was going with a study done by Oppermann et al. (2010). There are several examples of controversies and conflicting evidence based on ultrasound ovarian measurement. For example, Tomas et al. (2009) reported that ovarian volume correlates with the number of retrieved oocytes after controlled ovarian stimulation. The use of 3D ultrasound techniques did not appear to significantly increase the predictive power of ovarian volume as a screening tool for response to ovarian stimulation.

Regarding antral follicle count, the mean AFC by 2D and 3D ultrasound was $9.00 \pm 1.88$ (19 women had 6-8 follicles, 26 women had 9-11 follicles and 5 women had 12-13 follicles) with a non-significant difference. This was going with a study done by Jayaprakasan et al. (2008). The data in this study indicated that a pretreatment AFC measured using methods specific to 3D ultrasound offered minimal additional information from that derived from conventional 2D ultrasound in the prediction of the number of follicles measuring $10 \mathrm{~mm}$ or more. This was evident on the day of HCG, the actual number of oocytes was retrieved thereafter, and the incidence of nonconception. Furthermore, measurements made with the inversion mode took significantly longer than those made with the 2D equivalent and 3D multiplanar view techniques. The total AFC measured using any of the three methods is a better predictor of ovarian response than age, basal FSH levels and mean ovarian volume, none of these variables are predictive of non-conception (Antonio et al., 2016).

On the other hand, our study was not going with a study done by Scheffer et al. (2008), who noted a higher number of antral follicles when counts were made with 3D ultrasound rather than 2D ultrasound. This study has shown a comparable performance between the ' $2 \mathrm{D}$ equivalent' and the '3D multiplanar view' measurement methods in terms of the mean AFC.

Correlation between Anti-Mullerian hormone (AMH) level and ovarian reserve (antral follicle count and ovarian volume), our study showed non-significant difference. This was going with a study done by Van Voorhis (2010) who identified specific practices common to high-performing clinics which included 
ovarian reserve screening for all patients and the use of cycle day 3 FSH and AFC as a predictor of ovarian reserve instead $\mathrm{AMH}$. With specific regard to $\mathrm{AMH}$, they reported that only $30 \%$ of highperforming clinics used AMH to measure ovarian reserve. In contrast, Maheshwari et al. (2008) reported a significant relationship between $\mathrm{AMH}$ and ovarian reserve, they depended on $\mathrm{AMH}$ as a good predictor of ovarian reserve because age of the studied women was below 30 years and $\mathrm{AMH}$ was at a normal value.

\section{CONCLUSION}

- Transvaginal sonaography evaluated the ovarian reserve by the assessment of ovarian volume and antral follicle count.

- There was no difference between 2D and 3D ultrasound in the assessment of antral follicle count.

- The difference between 2D and 3D ultrasound in the assessment of ovarian volume was minimal and nonsignificant.

- AMH was non-significant in prediction of ovarian reserve.

\section{REFERENCES}

1. Antonio P., Gerado A., Fernando N., Yase R.C. and Fernando B-M. (2016): Evaluation of the ovarian reserve in young low responder with normal basal levels of follicle-stimulating hormone using three-Dimensional ultrasonography. Fertil Steril.,70(4):165-169.

2. Hansen R., Angela C.T., Michael R., Nancy A.K., Patrick M.S. and William J.B. (2017): Reproductive ageing and ovarian function: is the early follicular phase FSH rise necessary to maintain adequate secretory function in older ovulatory women? Hum. Reprod., 20(1):89-95.

3. Jayaprakasan K., Al-Hasie H. and Jayaprakasan R. (2008): The three-dimensional ultrasonographic ovarian vascularity of women developing poor ovarian response during assisted reproduction treatment and its predictive value. Fertil Steril., 92(6):18621869.

4. Maheshwari A, Hamilton $M$ and Bhattacharya S. (2008): A survey of clinicians' views on age and access to IVF and the use of tests of ovarian reserve prior to IVF in the United Kingdom. Hum Fertil (Camb), 11(1):23-7.

5. Oppermann, Skull J., McVeigh E., Margara R. and Winston RM. (2010): Measurement of ovarian volume by transvaginal sonography before ovulation induction with human menopausal gonadotrophin for in-vitro fertilization can predict poor response. Hum Reprod., 12:294-297.

6. Penarrubia J., Balach Y., Carmona F., Casals G., Casamitjana R., Creus M., Fabregues F., Manau D. and Yuan A. (2013): Basal and stimulation day 5 anti Mullerian hormone serum concentration as predictors of ovarian response and pregnancy in assisted reproductive technology cycles stimulated with gonadatropin - releasing hormone agonist gonadotropin treatment. Hum. Reprod., 20(4):915-922.

7. Scheffer G.J., Broekmans F.J., Bancsi L.F., Habbema J.D., Looman C.W. and Te Velde E.R. (2008): Quantitative transvaginal twoand three-dimensional sonography of the ovaries; reproducibility of antral follicle counts. Ultrasound Obstet Gynecol., 20: 270275.

8. Tevelde E.R. and Pearson P.L. (2010): The variability of female reproduction ageing. Hum. Reprod., 8: 141-154.

9. Tomas C., Nuojua-Huttunen S. and Martikainen H. (2009): Pretreatment transvaginal ultrasound examination predicts ovarian responsiveness to gonadotropins in in vitro fertilization. Hum. Reprod., 12:220-23.

10. Van Voorhis BJ (2010): What do consistently high-performing in vitro fertilization programs in the U.S. do? Fertil Steril, 94(4):1346-9.

11. Yohnson J., Conning J., Kaneko T., Pruy K. and Tilly Y.L. (2011): Germ line stem cells and follicular renewal in the postnatal mammalian ovary. Nature, 428: 145-150. 


\section{در اسة مقارنه بين الموجات فوق الصوتية ثلاثية الأبعاد وثنائية الأبعاد في تقييم مخزون البونيض ليضات في النساء اللاتي يخضعن للحقن المجهري}

يحيي عبد السلام وفا- محمد محمد جبريل - أحمد محمد رماح - حازم محمد توفيق ندا قسم أمراض النساء والتوليد - كلية الطب - جامعة الأزهر

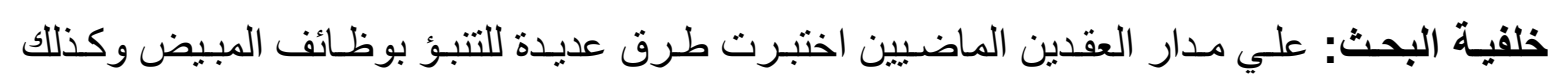

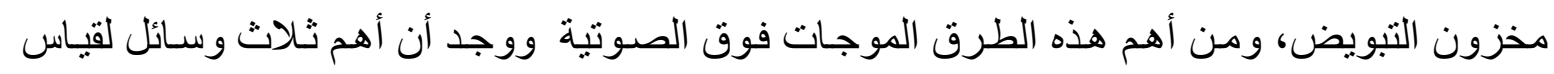

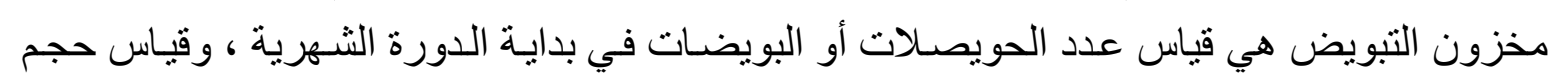
المبيض ، و أيضاً قياس الإمداد الدموي للمبيض.

الهلف من البحث: عمل مقارنـة بين الموجات فوق الصوتية ثلاثيـة الأبعاد وثنائية الأبعاد في تقييم

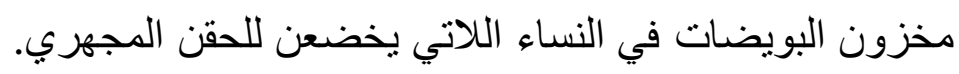

المرضي وطرق البحث: هذه الدراسة هي در اسة مستقبلية قمنا فيها باختيار خمسين سيده من السيدات

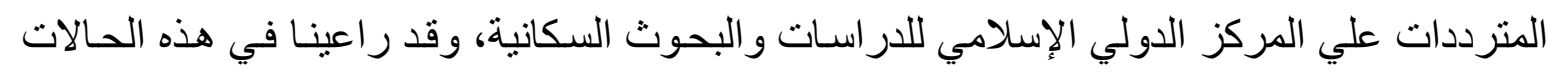

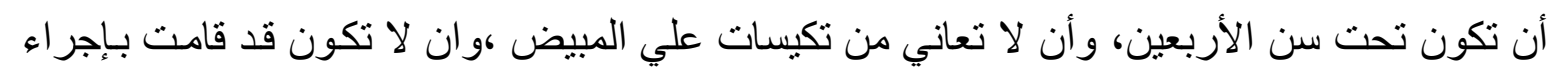

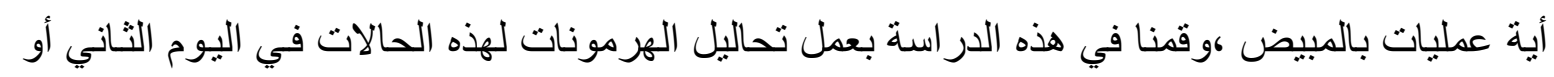

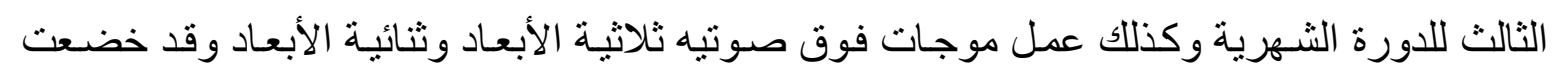

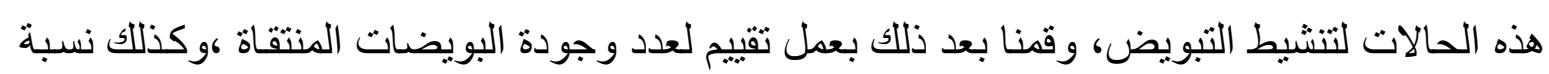
التخصيب بالإضافة إلى عدد وجودة الأجنة المنقولة.

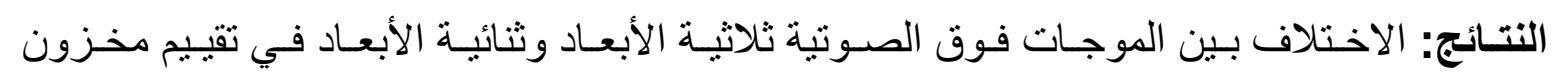

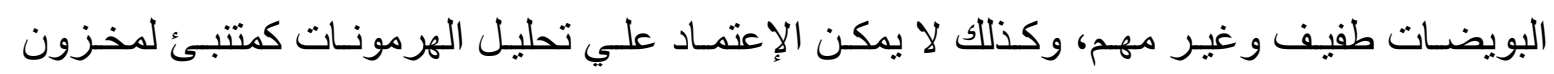
المبيض.

الإستنتاج: إستخدام الموجات فوق الصوتية من أهم الطرق في تقييم مخزون البويضـات في النساء

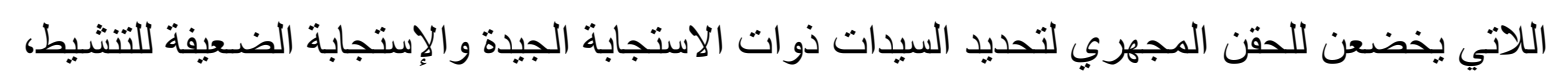
وذلك لتجنب فثل الحقن المجهري باهظ الثمن.

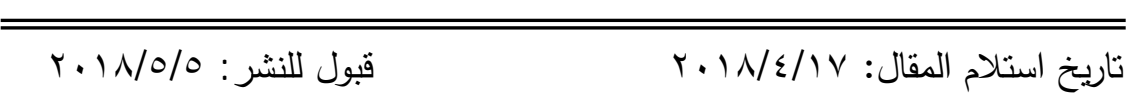

